\title{
Progressivity Trends in Municipal Property Taxes in Indian Cities: Major Impediments
}

\section{OPEN ACCESS}

Manuscript ID:

ECO-2021-09034022

Volume: 9

Issue: 3

Month: June

Year: 2021

P-ISSN: 2319-961X

E-ISSN: 2582-0192

Received: 12.04.2021

Accepted: 18.05.2021

Published: 01.06.2021

\section{Citation:}

Keekan, Preethi, and U. Arabi. "Progressivity Trends in Municipal Property Taxes in Indian Cities: Major Impediments." Shanlax International Journal of Economics, vol. 9, no. 3, 2021, pp. 45-48.

DOI:

https://doi.org/10.34293/ economics.v9i3.4022

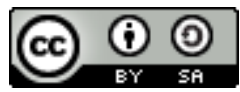

This work is licensed under a Creative Commons Attribution-ShareAlike 4.0 International License

\section{Preethi Keekan}

Research Scholar, Department of Economics

Mangalore University, Mangalore, Karnataka, India

https://orcid.org/0000-0002-7457-6729

\section{U. Arabi}

Professor, Department of Economics, Mangalore University, Mangalore, Karnataka, India

\section{Abstract}

Property taxes are widely acknowledged as an efficient and equitable means of raising revenue, but with revenue potential untapped mainly in many countries. Property taxes generally yield relatively modest income, particularly in developing and emerging economies. There's a need for improving the structure of the municipal property taxes and efforts to enhance its progressivity within the Indian Cities.

Keywords: Progressivity, Property tax, Tax administration

\section{Introduction}

Property tax is usually considered an appropriate source of accelerating local revenue because there's an immediate link between the services provided by the tax and, therefore, the advantage of property values. If the land tax is employed to fund local services, it establishes a link between the benefits and costs of local services to residents. This permits citizens to form efficient financial decisions. It's sometimes seen as a tax on capital that distorts the housing market and native financial choices. Within a tax, a Progressive rate structure is usually recommended to encourage equity and make yields more resilient. Tax is tax when the rate increases because the taxable amount increases. The term 'progressive' refers to how tax rates progress from low to high, leading to a lower taxpayer's average rate than a marginal rate per person. The term is often applied to individual tax or the whole legal system. Progressive taxes are imposed to scale back the tax incidence of low-income people, increasing the number of individuals with the power to pay higher taxes. There's a regressive tax as against a tax, like a nuisance tax, during which the poor pay a more significant share of their income than the rich.

In addition to being a tax on the beneficiaries of the local public services, it's argued that the land tax features a progressive distribution of the burden.

\section{Objectives}

- To study the nature and changes in the structural characteristics of the municipal property tax base and rates determining the legal tax capacity.

- To examine the trends in the progressivity of municipal property tax revenues with particular reference to GSDP-ratio and the policy parameters that influence the efficiency and equity of property tax mobilization. 
- To examine the role of policy and administrative factors interact to influence the efficiency and equity of property tax mobilization.

\section{Review of Literature}

Oates, 1969; The tax assumes the role of a quasibenefit charge and thus, is more acceptable and therefore evokes a greater degree of compliance. The land tax takes the character of a benefit tax as property owners enjoy public services provided by the local governments. It's also argued within the literature that fiscal differentials at the local levels capitalize on property values. This characteristic of the tax also makes it a tax.

Breton, 1996; It is implied that each broad-based and tax bases go the Central government and native governments will need to perform large and growing expenditure responsibilities.

Sennoga, et al., (2008) using a computable general equilibrium model with an outsized informal sector and fewer than perfect mobility of capital - the structural features to represent developing transitional countries show that the burden of property taxes is primarily borne by owners of land and money and thereby the distribution of tax burden is progressive.

\section{Data Analysis and Interpretation}

Progressive taxation is usually suggested to deal with the social problems related to high-income inequality, as inequality within the tax structure is reduced. Still, economists afflict the consequences of economic and long-term tax programs. One study suggests that progressive taxation could also be positively related to happiness, the subjective wellbeing of countries, and citizens' satisfaction with public goods like education and transportation.

\section{Economic Inequality}

Progressive taxation directly impacts reducing income inequality, mainly if money is employed for progressive government spendings like tax transfer payments and Social Security networks. However, if the evasion increases at a better level, the effect may subside.

States generally implement taxes that fall under one among three categories - income, wealth, and consumption, but there's a big difference in how each tax is adjusted. While trying to balance the various competitive targets for tax program determination, state policymakers can use five critical criteria to match the benefits and drawbacks of potential tax instruments:

- Economic Efficiency

- Equity

- Transparency

- Collectability and

- Revenue Production

The balance of these criteria helps increase the adequacy of funding for government services by reducing the number of distortions in the economy. Some requirements may conflict with one another.

\section{Economically Efficient Taxes Promote Growth}

The less a tax is considered economically practical, the less it changes decision-making. Taxes distort behavior when they cause somebody to make complex choices than to avoid taxes. The general guidelines that can help reduce the number of distortions in the economy include:

Lower Tax Rates: Lower taxes, less emphasis on homes and companies, so more residual income to buy, optimizing their well-being.

Broader Tax Bases: The most economically applicable taxes are usually levied equally on taxpayers. Adherence to this principle helps prevent the distorting effects caused by the tax system, which further increases deductions and itemization.

\section{An Equitable Tax System is a Fair System}

A tax is supposed equitable when likewise, situated individuals or businesses face the same tax responsibilities. States have many taxes that violate this standard because they disproportionately benefit some individuals and companies in the general public. Policymakers interested in an impartial system should pursue taxes that have both horizontal equity and vertical equity.

- Horizontal Equity occurs when two similarly situated taxpayers also face the same tax responsibilities. A tax lacks horizontal equity when two customers obtain the same amount of goods or assistance but pay a different amount in sales taxes, for example. 
- Vertical property occurs when two taxpayers who have the same income face the same tax responsibilities. A tax lacks perpendicular equity when the amount of the tax does not change among the taxpayer's ability to pay. A growing tax is when the tax bill faced by a taxpayer rises as the ability to pay increases. The opposite summary, when the total tax burden increases as the ability to pay declines, is called a regressive tax.

\section{Major Trends and Impediments of Municipal Property Tax in Indian Cities}

Seven major cities of India have been considered for the study, and they are Mumbai, Kolkata, Chennai, Bengaluru, Hyderabad, Ahmedabad, and Pune. A report by the World Economic Forum on 'Migration and Its Impact on Cities' finds that migration to Pune has increased rapidly in recent years. The colonial population of Pune has increased from about 370,000 migrants in 2001 (14\% of the population) to 660,000 ( $21 \%$ of the population) in 2011. Due to the high cost of living in Mumbai and the crowds, migrants have moved to Pune in search of better possibilities in all walks of life. It is now the target of choice for many citizens of Maharashtra for employment opportunities, education, healthcare services, real estate investments, and a better quality of life. The influx of immigrants increases the pressure on housing, infrastructure, and essential services. These emerging metropolitan regions have not made the necessary improvements to improve their administrative structure and financial convenience. In a general approach like business, they will suffer from similar congestion anomalies, environmental damage and social problems as large metropolitan regions have been suffering in recent decades. Following table 1 shows the annual growth rate of property tax and other taxes in the selected municipal cities.

Table 1: Annual Growth Rate of Property Tax and Other Taxes from 2012-13 to 2017-18 (\%)

\begin{tabular}{|l|c|c|}
\hline Municipal corporation & Property tax & Other tax \\
\hline Mumbai & 9.71 & -21.39 \\
\hline Bengaluru & 10.37 & 9.08 \\
\hline Hyderabad & 12.40 & NA \\
\hline
\end{tabular}

\begin{tabular}{|l|c|c|}
\hline Ahmedabad & 32.78 & 3.07 \\
\hline Chennai & 12.78 & 9.18 \\
\hline Pune & 17.48 & -21.61 \\
\hline Kolkata & -0.15 & 33.75 \\
\hline
\end{tabular}

Source: Various municipal reports 2012-13 to 2017-18

\section{Graph 1: Annual Growth rate of Property Tax} and Other Taxes from 2012-13 to 2017-18 (\%)

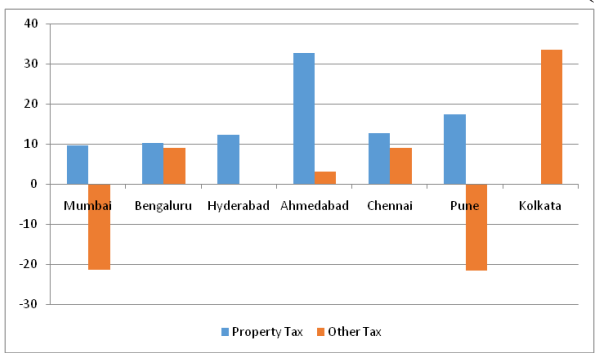

Source: Various Municipal reports 2012-13 to 2017-18

From the above table 1 and graph 1, it is observed that property tax growth rate shown a considerable increase only in Ahmedabad city with $32.78 \%$. In contrast, about Other tax collection, only Kolkata city showed a significant increase of $33.75 \%$ during the study period. All the selected cities except Ahmedabad have not offered many positive trends over the years. Hence it can say that the Property tax system should be reformed to make the Progressive tax system a success.

Table 2: Own Revenue and Property Tax per capita 2012-13 \& 2017-18 (Rs.)

\begin{tabular}{|l|c|c|c|c|}
\hline \multirow{2}{*}{$\begin{array}{c}\text { Municipal } \\
\text { corporation }\end{array}$} & \multicolumn{2}{|c|}{ Own Revenue } & \multicolumn{2}{c|}{ Property Tax } \\
\cline { 2 - 5 } & $\mathbf{2 0 1 2 - 1 3}$ & $\mathbf{2 0 1 7 - 1 8}$ & $\mathbf{2 0 1 2 - 1 3}$ & $\mathbf{2 0 1 7 - 1 8}$ \\
\hline Mumbai & 13769.6 & 13590.5 & 2620.1 & 4085.7 \\
\hline Bengaluru & 1920.8 & 2809.5 & 1232.4 & 1638.0 \\
\hline Hyderabad & 1955.4 & 2704.0 & 1068.7 & 1641.8 \\
\hline Ahmedabad & 1781.4 & 3889.6 & 432.5 & 1565.4 \\
\hline Chennai & 1757.4 & 3389.4 & 878.7 & 1550.0 \\
\hline Pune & 8448.1 & 6431.3 & 1377.5 & 2634.9 \\
\hline Kolkata & 3251.6 & 3127.7 & 1845.9 & 1848.0 \\
\hline
\end{tabular}

Source: Various municipal reports 2012-13 to 2017-18

Table 2 shows that Mumbai city had an excellent positive development in collecting a property tax over the years and all other cities have shown an increasing trend. Still, such a progressive rate is not sufficient as Property tax is regarded as the primary source of revenue of any municipal corporations 
for the public funding activities by the local bodies. Besides under-assessed values, cities also face wastefulness in billing and collection systems. Poor billing performance reflects the inability of urban local governments to cover all taxable properties in the tax net fully. With the rapid expansion of cities, imposing and taxing new properties remains a challenge.

Studies suggest the billing coverage of businesses ranges from $63 \%$ to $80 \%$. Thus, there is important potential to increase billing and collection effectiveness by using digital systems such as geographic knowledge systems and computerized billing and collection system. For increasing property tax coverage, a simple reform is to match the property records with monopoly data records from electricity companies.

\section{Conclusion}

The economic rationale for property tax is that it facilitates urban local bodies to capture a neighborhood of the "unearned" increase in property values. The argument is that urban business values rise as a result of foundation expenditures by urban local bodies. It's also a "progressive" tax, as higher value properties pay higher taxes. Alongside the fair valuation of property, periodic and regular reassessment of the land tax base is critical to bring evaluated values in line with market realities. In municipal Acts of the many states, it's recommended to hold out an assessment of properties once every five or four years. These reforms typically focused on improving the administration of tax, and in some cases, amid changes in the valuation of the assets.

\section{References}

Bagchi, Amaresh. "Reforming the Property Tax Base: Need for a New Direction." Economic \& Political Weekly, vol. 32, no. 47, 1997.

Bagchi, Soumen. "Politics and Economics of Property Taxation." Economic \& Political Weekly, vol. 38, no. 42, 2003.

Bandyopadhyay, Simanti. "Property Tax Reforms in Indian: A Comparison of Delhi and Bangalore." International Center for Public Policy Working Paper 13-21, 2013.

Best Practices in Property Tax Reforms in India. National Institute of Urban Affairs, Ministry of Urban Development, 2010.

Bird, Richard M., and Enid Slack. The Role of the Property Tax in Financing Rural Local Governments in Developing Countries. 2006.

Bird, Richard M., and Enid Slack. "An Approach to Metropolitan Governance and Finance." Environment and Planning C: Politics and Space, vol. 25, no. 5, 2007, pp. 729-755.

Dhawan, B.D. "Cost of Tax Collection in India - A Comment." Economic \& Political Weekly, vol. 3, no. 16, 1968.

Mathur, Om Prakash, et al. Urban Property Tax Potential in India. National Institute of Public Finance and Policy, 2009.

Mohanty, P.K., et al. Municipal Finance in India: An Assessment. Department of Economic Analysis and Policy, Reserve Bank of India, 2007.

Municipal statistical Reports 2012-13 to 2017-18.

Oates, Wallace E. "The Effect of Property Taxes on Local Public Spending on Property Values: An Empirical Study of Tax Capitalization and the Tiebout Hypothesis." Journal of Political Economy, vol. 77, no. 6, 1969, pp. 957-971.

\section{Author Details}

Mrs. Preethi Keekan, Research Scholar, Department of Economics, Mangalore University, Mangalore, Karnataka, India,Email ID: keekanpreethi@gmail.com.

U. Arabi, Professor, Department of Economics, Mangalore University, Mangalore, Karnataka, India. 